\title{
The role of intraoperative pulmonary arterial catheterization data in determining the need for extracorporeal membrane oxygenation in lung transplantation
}

\author{
Akciğer naklinde intraoperatif pulmoner arter kateterizasyon verilerinin ekstrakorporeal membran \\ oksijenasyon intiyacını belirlemedeki rolü
}

\author{
Pınar Karaca Baysal ${ }^{\circ}$, Atakan Erkılınç $@$, Mustafa Emre Gürcü $®$
}

Department of Anesthesiology and Reanimation, Kartal Koşuyolu Yüksek Ihtisas Training and Research Hospital, Istanbul, Turkey

\begin{abstract}
Background: This study aims to investigate predictive factors of identification of the need of patients for extracorporeal membrane oxygenation support during lung transplantation.

Methods: A total of 63 patients (49 males, 14 females, mean age: $44.9 \pm 14.4$ years; range, 14 to 64 years) who underwent lung transplantation in our institution between December 2016 and December 2019 were retrospectively analyzed. Demographic characteristics and perioperative clinical data of patients were recorded. After induction and pulmonary artery catheterization, cardiac output, mean pulmonary artery pressure, pulmonary capillary wedge pressure, cardiac index, pulmonary vascular resistance, systemic vascular resistance, and right atrial pressure were measured using the thermodilution technique.

Results: Thirty-three of the patients received extracorporeal membrane oxygenation support during surgery. The right atrial pressure $(\mathrm{p}<0.001)$, pulmonary capillary wedge pressure $(\mathrm{p}<0.002)$, mean pulmonary artery pressure $(\mathrm{p}<0.001)$, and pulmonary vascular resistance $(\mathrm{p}<0.001)$ were statistically significantly higher in the patients who required extracorporeal membrane oxygenation support intraoperatively. The systemic vascular resistance $(\mathrm{p}<0.032)$ was statistically significantly lower in the patients who required extracorporeal membrane oxygenation support intraoperatively. A mean pulmonary artery pressure of $>39 \mathrm{mmHg}(\mathrm{p}<0.02)$ and a right atrial pressure of $>12 \mathrm{mmHg}(\mathrm{p}<0.047)$ were independent risk factors for ECMO support intraoperatively during lung transplantation.

Conclusion: Predicting the need of intraoperative extracorporeal membrane oxygenation support is of utmost importance in timing the need for mechanical support, protecting the new graft from high mechanical ventilator pressures, and adequately maintaining hemodynamic stability.
\end{abstract}

Keywords: Extracorporeal membrane oxygenation, lung transplantation, pulmonary artery catheterization, pulmonary hypertension.
$\ddot{O} Z$

Amaç: $\mathrm{Bu}$ çalışmada, akciğer nakli sırasında hastaların intraoperatif ekstrakorporeal membran oksijenasyon destek ihtiyacını belirleyen öngördürücü faktörler araştırıldı.

Çalışma planı: Aralık 2016 - Aralık 2019 tarihleri arasında hastanemizde akciğer nakli olan toplam 63 hasta (49 erkek,

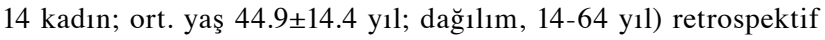
olarak incelendi. Hastaların demografik özellikleri ve perioperatif klinik verileri kaydedildi. İndüksiyon ve pulmoner arter kateterizasyonu sonrasinda kalp debisi, ortalama pulmoner arter basıncı, pulmoner kapiller kama basıncı, kardiyak indeks, pulmoner vasküler direnç, sistemik vasküler direnç ve sağ atriyal basınç termodilüsyon tekniği ile ölçüldü.

Bulgular: Hastaların 33'ü ameliyat sırasında ekstrakorporeal membran oksijenasyon desteği aldı. Ameliyat sırasında ekstrakorporeal membran oksijenasyon desteği gereken hastalarda sağ atriyal basınç $(\mathrm{p}<0.001)$, pulmoner kapiller kama basıncı $(\mathrm{p}<0.002)$, ortalama pulmoner arter basinc1 $(\mathrm{p}<0.001)$ ve pulmoner vasküler direnç $(\mathrm{p}<0.001)$ istatistiksel olarak anlamlı düzeyde yüksekti. Sistemik vasküler direnç $(\mathrm{p}<0.032)$ ise, ameliyat sırasında ekstrakorporeal membran oksijenasyon desteği alan hastalarda istatistiksel olarak anlamlı düzeyde düşüktü. Ortalama pulmoner arter basıncının $>39 \mathrm{mmHg}(\mathrm{p}<0.02)$ ve sağ atriyal basıncın $>12 \mathrm{mmHg}(\mathrm{p}<0.047)$ olması, akciğer nakli sırasında intraoperatif olarak ekstrakorporeal membran oksijenasyon desteğinin bağımsız risk faktörleri idi.

Sonuç: İntraoperatif dönemde ekstrakorporeal membran oksijenasyon desteğine duyulan ihtiyacın öngörülebilmesi; mekanik destek ihtiyacının zamanlaması, yüksek mekanik ventilatör basınçlarından yeni greftin korunması ve hemodinamik stabilitenin etkin bir şekilde sürdürülebilmesi açısından oldukça önemlidir.

Anahtar sözcükler: Ekstrakorporeal membran oksijenasyonu, akciğer nakli, pulmoner arter kateterizasyonu, pulmoner hipertansiyon.

Received: July 15, 2020 Accepted: December 20, 2020 Published online: October 20, 2021

Correspondence: Pınar Karaca Baysal, MD. Kartal Koşuyolu Yüksek Ihtisas Eğitim ve Araşłırma Hastanesi, Anestezi ve Reanimasyon Kliniği, 34865 Kartal, İstanbul, Türkiye. Tel: +90 532 - 1552034 e-mail: drpinarkaraca@hotmail.com 
Lung transplantation (LTx) is the most effective treatment method for end-stage lung diseases. ${ }^{[1]}$ It can cause various clinical problems due to the diversity of the underlying pathologies and the difficulties of surgical procedure. ${ }^{[2]}$ Hemodynamic instability and respiratory problems are frequently encountered during the induction of anesthesia, single-lung ventilation (SLV), clamping/declamping of the pulmonary artery, pulmonary reperfusion, ventilation of the new graft, and left lung anastomosis. ${ }^{[3-5]}$

Problems that arise during LTx have been currently overcome by intraoperative extracorporeal membrane oxygenation (ECMO) support. However, no specific criterion is used to predict the need for intraoperative use of ECMO ${ }^{[6]}$ Predicting these patients that would require intraoperative ECMO use would enable us a more controlled and effective management of LTx anesthesia. ${ }^{[7]}$

Intraoperative hemodynamic monitoring is of utmost importance in anesthesia management of LTx operations. ${ }^{[8,9]}$ The monitorization of pulmonary pressure through pulmonary artery catheterization (PAC), measurement of right/left ventricular functions, and monitorization of pulmonary vascular resistance (PVR) and preload/afterload indices may provide an effective anesthesia management. ${ }^{[10]}$

In the present study, we aimed to investigate whether PAC data measured after the induction of anesthesia could predict the need for intraoperative ECMO use.

\section{PATIENTS AND METHODS}

This single-center, retrospective study was conducted at Kartal Koşuyolu Yüksek Ihtisas Training and Research Hospital, Department of Anesthesiology and Reanimation between December 2016 and December 2019. A total of 71 patients who underwent LTx were screened. Eight of these patients were excluded from the study, as they received ECMO support in the preoperative period. Three out of eight patients were excluded, as they underwent emergency ECMO after the induction. Finally, a total of 63 patients (49 males, 14 females, mean age: $44.9 \pm 14.4$ years; range, 14 to 64 years) were included in the study. A written informed consent was obtained from each patient. The study protocol was approved by the Institutional Review Board of Kartal Koşuyolu Training and Research Hospital (Date/No: 25.08.2020/2020/6/343). The study was conducted in accordance with the principles of the Declaration of Helsinki.
The data were retrieved from the clinical records of the hospital database. Demographic and clinical characteristics and perioperative clinical data including blood gases, hemodynamic data, essential findings, and ECMO use were recorded.

A five-lead electrocardiogram device, pulse oximeter, invasive blood pressure measurement from the left radial or brachial artery, urine output monitorization, transesophageal echocardiography for cardiac monitorization and near-infrared spectroscopy (INVOSTM, Somanetics/Covidien, Boulder, CO, USA) for cerebral oxygenation monitorization were used.

Following the induction of anesthesia, an endobronchial tube was inserted to the side that showed the highest ventilation/perfusion (V/Q) scintigraphic values. A pediatric fiberoptic bronchoscope was used to check for the position of the tube. In addition, 35, 37, and 39-Fr (Shiley ${ }^{\mathrm{TM}}$ endobronchial tube; Covidien Medtronic, Watford, UK) endobronchial tubes were used considering the patient's age, weight, and height. The mechanical ventilator settings were adjusted to optimize blood gases.

After intubation, a central venous catheter (8.5-Fr Arrow International Inc., PA, USA) and a pulmonary catheter $\left(A_{R R O W}{ }^{\circledR}\right.$ 7.5-Fr, 5 Lumen HANDS-OFF infusion port thermodilution catheter) were inserted through the right jugular vein. Central catheterization was performed using the Seldinger technique, and central venous pressure (CVP) was measured. Following PAC, cardiac output (CO), mean pulmonary artery pressure (mPAP), pulmonary capillary wedge pressure (PCWP), cardiac index (CI), PVR, systemic vascular resistance (SVR), and right atrial pressure (RAP) were measured using the thermodilution technique.

The CO measurements were performed following induction when hemodynamic and respiratory parameters were most stable to prevent the effects of factors such as hypoxia and hypotension on $\mathrm{CO}$ measurement. The optimal conditions for $\mathrm{CO}$ measurements were defined as a mean arterial pressure (MAP) of $>60 \mathrm{mmHg}, \mathrm{SaO}_{2}$ of $>96 \%$, and partial pressure of oxygen $\left(\mathrm{PaO}_{2}\right)$ of $>80 \mathrm{mmHg}$ and partial pressure of carbon dioxide $\left(\mathrm{PaCO}_{2}\right)$ of $>50 \mathrm{mmHg}$. Patients who did not meet these criteria and experienced refractory impairment in hemodynamic and respiratory parameters received emergency ECMO and excluded from the study.

When the pulmonary artery catheter was placed to the side to be clamped during surgery, the catheter was 
withdrawn and inserted to the contralateral pulmonary artery for continuous monitorization of pulmonary pressures.

\section{Intraoperative ECMO}

Patients who received ECMO during surgery were those who experienced hemodynamic and respiratory instability at any time during operation. Notably, patients with refractory hemodynamic instability (MAP $<50 \mathrm{mmHg}$ ) at any time during surgery despite the administration of inotropic agents received ECMO support. The ECMO support provided during the operation was in the form of veno-arterial (VA)-ECMO in all patients.

The patients were administered with heparin $60 \mathrm{U} / \mathrm{kg}$ after opening the thoracic cavity, and the coagulation status was monitored by the measurement of activated clotting time (ACT). An ACT of 150 to 180 was targeted. In general, an 18 -Fr cannula was inserted into the aorta, and a $32-\mathrm{Fr}$ cannula was inserted into the right atrium. After connecting the ECMO cannula to the system, the flow rate of ECMO was increased slowly to stabilize hemodynamics and gas exchange.

At the end of the operation, patients undergoing ECMO were evaluated for weaning. The ECMO support was terminated, if the patient was hemodynamically stable with $\mathrm{PaO}_{2} 90$ to $100 \mathrm{mmHg}$,
$\mathrm{PaCO}_{2} 35$ to $45 \mathrm{mmHg}$, mixed venous oxygen saturation $\left(\mathrm{SvO}_{2}\right) 65$ to $75 \%$ in the blood gas analysis and, if the tidal volume was 8 to $10 \mathrm{~mL} / \mathrm{kg}$, the respiratory frequency was within normal ranges, the patient could breathe with positive end-expiratory pressure within acceptable limits $\left(10 \mathrm{cmH}_{2} \mathrm{O}\right)$, and there were no findings of low pulmonary reserves and right ventricular (RV) failure. Patients not meeting the prespecified clinical criteria were transferred to the intensive care unit while under ECMO support.

\section{Statistical analysis}

Statistical analysis was performed using the SPSS version 15.0 software (SPSS Inc., Chicago, IL, USA). The Kolmogorov-Smirnov test was used to determine whether the continuous data were normally distributed. Continuous variables were expressed in mean \pm standard deviation (SD) or median (min-max), while categorical variables were expressed in number and frequency. Differences between the groups were evaluated using the Student t-test or Pearson chi-square test. The CO measurements were analyzed by an independent t-test, and those predicting intraoperative ECMO with a $p$ value of $<0.05$ were included in the regression model. Univariate and multivariate logistic regression analyses were performed to identify predictive sensitivity of the $\mathrm{CO}$ measurements associated with intraoperative ECMO implantation.

Table 1. Demographic data and cardiac measurements of patients

\begin{tabular}{lcc}
\hline & Mean \pm SD & Min-Max \\
\hline Age (year) & $44.9 \pm 14.4$ & $14-64$ \\
Body mass index $\left(\mathrm{kg} / \mathrm{m}^{2}\right)$ & $23.5 \pm 5.1$ & $13-48$ \\
Cardiac index & $2.7 \pm 0.8$ & $1.48-4.70$ \\
Systemic artery pressure & $108.7 \pm 16.9$ & $71-170$ \\
Diastolic artery pressure & $63.7 \pm 11.6$ & $22-83$ \\
Heart rate & $90.6 \pm 16.0$ & $52-123$ \\
Pulmonary vascular resistance & $488.4 \pm 291.9$ & $116-1,594$ \\
Pulmonary vascular resistance index & $712.2 \pm 298.6$ & $194-2,187$ \\
Systemic vascular resistance & $1,312.2 \pm 4,13.8$ & $529-2,522$ \\
Systemic vascular resistance index & $2,149.4 \pm 6,88.8$ & $761-4,205$ \\
Systolic pulmonary artery pressure & $51.4 \pm 22.0$ & $20-117$ \\
Mean pulmonary artery pressure & $36.0 \pm 15.4$ & $10-82$ \\
Pulmonary capillary wedge pressure & $16.7 \pm 7$ & $7-50$ \\
Right ventricular stroke volume index & $14.6 \pm 5.2$ & $3.24-34.34$ \\
Right atrial pressure & $11.5 \pm 3.2$ & $6-21$ \\
\hline
\end{tabular}

SD: Standard deviation. 
Odds ratios (ORs) were presented in $95 \%$ confidence interval. Area under the curve (AUC) values were obtained using the MedCalc version 20.011 software (MedCalc Software Ltd., Ostend Belgium). In the receiver operating characteristics (ROC) curve analysis, the AUC values of $\mathrm{CO}$ measurements were calculated on intraoperative ECMO implantation. A $p$ value of $<0.05$ was considered statistically significant.

\section{RESULTS}

Of a total of 63 patients included in the study, 33 received ECMO support during surgery. Age, body mass index (BMI), and $\mathrm{CO}$ measurements after the induction are presented in Table 1. The mean CI, PAP, mPAP, and PCWP values were
$2.7 \pm 0.8 \mathrm{~L} / \mathrm{min} / \mathrm{m}^{2}, 51.4 \pm 22 \mathrm{mmHg}, 36 \pm 15.4 \mathrm{mmHg}$, and $16.7 \pm 7 \mathrm{mmHg}$, respectively. The mean RAP and RVSWi values were $11.5 \pm 3.2 \mathrm{mmHg}$ and $14.6 \pm 5.2$ g.m $/ \mathrm{m}$, respectively.

Table 2 shows the relationship between age, gender, BMI, etiology, and ECMO use, indicating no statistically significant relationship. The relationship between $\mathrm{CO}$ measurements and ECMO use was also investigated in this table. The RAP $(\mathrm{p}<0.001)$, PCWP $(\mathrm{p}<0.002)$, mPAP $(\mathrm{p}<0.001)$, and PVR $(\mathrm{p}<0.001)$ were statistically significantly higher in the patients who required ECMO support intraoperatively than those who did not. The SVR $(p<0.032)$ was statistically significantly lower in the patients who required ECMO support intraoperatively than those who did not. A comparison between the patients who

Table 2. Relationship between demographic data, disease etiology, intraoperative cardiac measurements, extubation time, mortality, and ECMO use

\begin{tabular}{|c|c|c|c|c|c|c|c|}
\hline & \multicolumn{3}{|c|}{ ECMO (-) } & \multicolumn{3}{|c|}{ ECMO (+) } & \multirow[b]{2}{*}{$p$} \\
\hline & $\mathrm{n}$ & $\%$ & Mean \pm SD & $\mathrm{n}$ & $\%$ & Mean \pm SD & \\
\hline Age (year) & & & $48.1 \pm 12.2$ & & & $42.0 \pm 15.8$ & $0.092^{\mathrm{c}}$ \\
\hline Sex & & & & & & & $0.840^{\mathrm{b}}$ \\
\hline Female & 7 & 23.3 & & 7 & 21.2 & & \\
\hline Male & 23 & 76.7 & & 26 & 78.8 & & \\
\hline Body mass index $\left(\mathrm{kg} / \mathrm{m}^{2}\right)$ & & & $24.9 \pm 5.3$ & & & $22.2 \pm 4.5$ & $0.061^{\mathrm{c}}$ \\
\hline Etiology & & & & & & & $0.062^{\mathrm{a}}$ \\
\hline Idiopathic pulmonary fibrosis & 14 & 46.7 & & 11 & 44 & & \\
\hline COPD & 8 & 26.7 & & 19 & 57.6 & & \\
\hline Cystic fibrosis & 4 & 13.3 & & 1 & 3 & & \\
\hline Cancer & 0 & 0 & & 1 & 3 & & \\
\hline Sarcoidosis & 1 & 3.3 & & 1 & 3 & & \\
\hline Silicos & 3 & 10 & & 0 & 0 & & \\
\hline Systemic artery pressure & & & $108.0 \pm 15.1$ & & & $109.4 \pm 18.6$ & $0.741^{\mathrm{c}}$ \\
\hline Cardiac index & & & $2.6 \pm 0.6$ & & & $2.8 \pm 0.9$ & $0.359^{\mathrm{c}}$ \\
\hline Diastolic artery pressure & & & $63.6 \pm 12.4$ & & & $63.9 \pm 11.0$ & $0.933^{\mathrm{c}}$ \\
\hline Heart rate & & & $88.6 \pm 16.7$ & & & $92.4 \pm 15.4$ & $0.351^{\mathrm{c}}$ \\
\hline Pulmonary vascular resistance & & & $364.2 \pm 164.0$ & & & $601.3 \pm 336.3$ & $0.001^{\mathrm{c}}$ \\
\hline Systemic vascular resistance & & & $1,428.3 \pm 359.6$ & & & $1,206.6 \pm 436.3$ & $0.032^{c}$ \\
\hline Mean pulmonary artery pressure & & & $28.6 \pm 11.7$ & & & $42.7 \pm 15.4$ & $<0.001^{\mathrm{c}}$ \\
\hline Pulmonary capillary wedge pressure & & & $13.9 \pm 5.0$ & & & $19.2 \pm 7.7$ & $0.002^{\mathrm{c}}$ \\
\hline Right atrial pressure & & & $10.1 \pm 2.7$ & & & $12.8 \pm 3.1$ & $<0.001^{\mathrm{c}}$ \\
\hline Extubation time & & & $47.5 \pm 51.1$ & & & $43.9 \pm 39.0$ & $0.756^{\mathrm{c}}$ \\
\hline 30-Day mortality & & & & & & & $0.234^{\mathrm{b}}$ \\
\hline No & 24 & 80 & & 22 & 66.7 & & \\
\hline Yes & 6 & 20 & & 11 & 33.3 & & \\
\hline
\end{tabular}

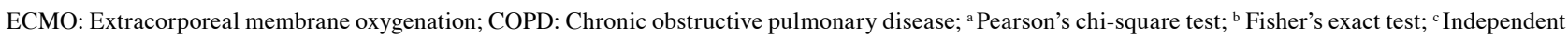
samples t-test. 
Table 3. Cut-off values, sensitivity, specificity, PPV, NPV AUC values of factors associated with ECMO use

\begin{tabular}{|c|c|c|c|c|c|c|}
\hline Test & Cut-point & Sensitivity (\%) & Specificity (\%) & PPV (\%) & NPV (\%) & AUC \\
\hline mPAP & $>39$ & 60.6 & 90 & 87.5 & 67.5 & 0.742 \\
\hline PCWP & $>18$ & 57.6 & 90 & 86.4 & 65.9 & 0.727 \\
\hline PVR & $>570$ & 45.5 & 96.7 & 93.8 & 61.7 & 0.664 \\
\hline RAP & $>12$ & 51.5 & 86.7 & 81 & 61.9 & 0.714 \\
\hline SVR & $\leq 2077$ & 66.7 & 73.3 & 73 & 66.7 & 0.727 \\
\hline
\end{tabular}

PPV: Positive predictive value; NPV: Negative predictive value; AUC: Area under curve; ECMO: Extracorporeal membrane oxygenation; mPAP: Mean pulmonary artery pressure; PCWP: Pulmonary capillary wedge pressure; PVR: Pulmonary vascular resistance; RAP: Right atrial pressure; SVR: Systemic vascular resistance.

received and did not receive ECMO support during surgery revealed no significant difference in terms of 30-day mortality and extubation times.

In the multivariate analysis, mPAP $>39 \mathrm{mmHg}$ $(\mathrm{p}<0.02)$ and RAP $>12 \mathrm{mmHg}(\mathrm{p}<0.047)$ were independent risk factors for ECMO support intraoperatively during LTx (Table 3).

In the ROC curve analysis, the cut-off value for mPAP was $39 \mathrm{mmHg}(\mathrm{AUC}=0.742)(\mathrm{p}=0.001)$, while the cut-off value for RAP was $12 \mathrm{mmHg}(\mathrm{AUC}=0.714)$ $(\mathrm{p}=0.001)$.

\section{DISCUSSION}

In the present study, we evaluated the value of $\mathrm{CO}$ measurements in predicting ECMO requirement, and a mPAP of $>39 \mathrm{mmHg}$ and a RAP of $>12 \mathrm{mmHg}$ were found to be independent predictors for ECMO need.

Lung transplantation is a life-saving procedure in end-stage lung diseases. ${ }^{[7]}$ The number of LTx procedures has been increasing recently. However, the scarcity of donors in Turkey brings about the necessity of considering even marginal donors. The more marginal is the donor, the higher is the risk for the recipient, necessitating a more complicated anesthesia management which is associated with complications. ${ }^{[11]}$

During LTx, ECMO can be preferred as the mechanical supportive device in patients experiencing refractory hemodynamic and respiratory problems that cannot be corrected by conventional methods. ${ }^{[11,12]}$ The ECMO has an increasing use during surgery to eliminate complications such as pulmonary hypertension, and RV failure and global hypoxia/hypercarbia caused by clamping of the pulmonary hilus. ${ }^{[12]}$ Therefore, close hemodynamic monitorization and the use of ECMO in the case of hemodynamic instability are particularly crucial in the management of LTx anesthesia.
Although ECMO plays an essential role in LTx anesthesia, the lack of established practical criteria for intraoperative use of ECMO support remains a problem. Hemodynamic parameters such as preoperative RV ejection fraction and pulmonary artery pressure have been suggested as a predictor in the literature; however, no guidelines have been established yet. ${ }^{[6]}$

Pulmonary hypertension has a diverse range of effects on cardiac anatomy and physiology. It may cause RV dilation and hypertrophy, tricuspid regurgitation and, consequently, cardiac dysfunction..$^{[13,14]}$ Pulmonary artery catheterization is an indispensable monitorization instrument to detect such intracardiac physiopathological processes and direct the therapy, when necessary. ${ }^{[15]}$ The PAC may guide the treatment by enabling the measurement of cardiac output, pulmonary artery pressure, $\mathrm{SvO}_{2}$, cardiac preload, and RV parameters. ${ }^{[16,17]}$

Severe pulmonary hypertension may occur in case of refractory hypoxia and hypercarbia. Surgical retraction during left lung anastomosis may cause systemic hypotension, pulmonary hypertension, and severe arrhythmias. Furthermore, when the ipsilateral pulmonary artery of the same operation side is clamped, blood circulates only in the native lung, leading to relative hypervolemia and right heart failure. ${ }^{[15]}$ The ECMO is the commonly preferred method to overcome such intraoperative problems that frequently arise. ${ }^{[18]}$

In the present study, PAC was performed in all patients, and CO, PVR, SVR, PCWP, and RAP were measured after the induction of anesthesia. In our series, CO parameters, including PVR, SVR, mPAP, PCWP and RAP, were found to predict the need for intraoperative ECMO. Among these parameters, mPAP and RAP were independent predictors. In the ROC curve analysis, the cut-off value in predicting 
intraoperative ECMO need was $39 \mathrm{mmHg}$ for $\mathrm{mPAP}$ and $12 \mathrm{mmHg}$ for RAP.

Pulmonary artery pressure over $85 \mathrm{mmHg}$ in LTx is a poor prognostic factor. ${ }^{[19]}$ In addition, ECMO is required routinely when the MPAP rises above $40 \mathrm{mmHg}$ after pulmonary artery clamping. ${ }^{[20]}$ Also, Hinske et al ${ }^{[7]}$ reported that a preoperative mPAP of $\geq 35 \mathrm{mmHg}$ was predictive for intraoperative ECMO support. The authors suggested that preoperative parameters were more valuable among the pulmonary pressure values. In the present study, mPAP value was measured after intubation, when the patient was stable. When a patient was added to the LTx waiting list, we observed that preoperative pulmonary pressures measured in the catheterization laboratory did not match the values measured during surgery. Considering a prolonged waiting period and the progression in the pulmonary pathology, higher pulmonary pressure values can be expected during operation. Therefore, we believe that pulmonary pressure values measured before the induction of anesthesia are more valuable in predicting the clinical and hemodynamic condition of the patient and possible need for ECMO support.

In two previous studies, a CI value of less than 1.8 and $2 \mathrm{~L} / \mathrm{min} / \mathrm{m}^{2}$ was reported to be associated with poor prognosis, respectively. ${ }^{[20,21]}$ However, in a study by Hirt et al., ${ }^{[6]}$ a decrease in CI more than $1.5 \mathrm{~L} / \mathrm{min} / \mathrm{m}^{2}$ after clamping of the pulmonary artery was a determinant for intraoperative ECMO requirement. In the statistical analysis in our series, CI was not found to be a predictor of intraoperative ECMO need, as only one patient in our series had a CI value of $1.48 \mathrm{~L} / \mathrm{min} / \mathrm{m}^{2}$ and the mean CI in our series was $2.7 \pm 0.8 \mathrm{~L} / \mathrm{min} / \mathrm{m}^{2}$. Furthermore, changes in the CI could not be monitored after pulmonary artery clamping, as continuous intraoperative $\mathrm{CO}$ monitorization was not performed in our study.

The RAP increases as a result of remodeling in the right heart that is exposed to high pulmonary pressure. ${ }^{[22,23]}$ A RAP of $>20$ to $15 \mathrm{mmHg}$ was reported to be a poor prognostic factor in previous studies. ${ }^{[20,24-26]}$ In a recent study, however, Sitbon et al. ${ }^{[27]}$ found that a RAP of $>12 \mathrm{mmHg}$ increased mortality. Nevertheless, none of these studies evaluated the use of RAP in predicting intraoperative ECMO use. In the present study, on the other hand, a RAP value of $>12 \mathrm{mmHg}$ was found to predict intraoperative ECMO requirement.

The retrospective and single-center design of the study with a relatively small sample size are the main limitations of this study. We believe that further multi- center, large-scale, prospective studies may provide more accurate data regarding the factors predicting intraoperative ECMO requirement in LTx.

In conclusion, lung transplantation anesthesia is challenging due to associated complications and the existing pulmonary physiopathology. Therefore, unexpected intraoperative clinical problems jeopardize the success of the anesthesia procedure. Predicting the need for extracorporeal membrane oxygenation support is of paramount importance in timing the need for mechanical support, protecting the new graft from high mechanical ventilator pressures, and adequately maintaining hemodynamic stability.

\section{Declaration of conflicting interests}

The authors declared no conflicts of interest with respect to the authorship and/or publication of this article.

\section{Funding}

The authors received no financial support for the research and/or authorship of this article.

\section{REFERENCES}

1. Myles PS, Weeks AM, Buckland MR, Silvers A, Bujor M, Langley M. Anesthesia for bilateral sequential lung transplantation: Experience of 64 cases. J Cardiothorac Vasc Anesth 1997;11:177-83.

2. Slinger P. Anaesthetic management for lung transplantation. Tx Med 2012;24:27-34.

3. Baez B, Castillo M. Anesthetic considerations for lung transplantation. Semin Cardiothorac Vasc Anesth 2008;12:122-7.

4. Miranda A, Zink R, McSweeney M. Anesthesia for lung transplantation. Semin Cardiothorac Vasc Anesth 2005;9:205-12.

5. SerraE,Feltracco P,BarbieriS, Forti A, OriC. Transesophageal echocardiography during lung transplantation. Transplant Proc 2007;39:1981-2.

6. Hirt SW, Haverich A, Wahlers T, Schäfers HJ, Alken A, Borst HG. Predictive criteria for the need of extracorporeal circulation in single-lung transplantation. Ann Thorac Surg 1992;54:676-80.

7. Hinske LC, Hoechter DJ, Schröeer E, Kneidinger N, Schramm R, Preissler G, et al. Predicting the necessity for extracorporeal circulation during lung transplantation: A feasibility study. J Cardiothorac Vasc Anesth 2017;31:931-8.

8. De Wolf AM. Pulmonary artery catheter: Rest in peace? Not just quite yet... Liver Transpl 2008;14:917-8.

9. De Wolf AM, Aggarwal S. Monitoring preload during liver transplantation. Liver Transpl 2008;14:268-9.

10. Della Rocca G, Costa GM, Coccia C, Pompei L, Di Marco P, Pietropaoli P. Preload index: Pulmonary artery occlusion pressure versus intrathoracic blood volume monitoring during lung transplantation. Anesth Analg 2002;95:835-43 
11. Tomasi R, Betz D, Schlager S, Kammerer T, Hoechter DJ, Weig $\mathrm{T}$, et al. Intraoperative anesthetic management of lung transplantation: Center-specific practices and geographic and centers size differences. J Cardiothorac Vasc Anesth 2018;32:62-9.

12. Hoetzenecker K, Schwarz S, Muckenhuber M, Benazzo A, Frommlet F, Schweiger $\mathrm{T}$, et al. Intraoperative extracorporeal membrane oxygenation and the possibility of postoperative prolongation improve survival in bilateral lung transplantation. J Thorac Cardiovasc Surg 2018;155:2193-206.e3.

13. Kusunose K, Agarwal S, Marwick TH, Griffin BP, Popović ZB. Decision making in asymptomatic aortic regurgitation in the era of guidelines: incremental values of resting and exercise cardiac dysfunction. Circ Cardiovasc Imaging 2014;7:352-62.

14. Ling LF, Marwick TH. Echocardiographic assessment of right ventricular function: How to account for tricuspid regurgitation and pulmonary hypertension. JACC Cardiovasc Imaging 2012;5:747-53.

15. Nagendran M, Maruthappu M, Sugand K. Should double lung transplant be performed with or without cardiopulmonary bypass? Interact Cardiovasc Thorac Surg 2011;12:799-804.

16. Della Rocca G, Brondani A, Costa MG. Intraoperative hemodynamic monitoring during organ transplantation: What is new? Curr Opin Organ Transplant 2009;14:291-6.

17. Della Rocca G, Costa MG, Coccia C, Pompei L, Di Marco P, Vilardi V, et al. Cardiac output monitoring: Aortic transpulmonary thermodilution and pulse contour analysis agree with standard thermodilution methods in patients undergoing lung transplantation. Can J Anaesth 2003;50:707-11.

18. Mitoff PR, Beauchesne L, Dick AJ, Chow BJ, Beanlands RS, Haddad $\mathrm{H}$ et al. Imaging the failing right ventricle. Curr Opin Cardiol 2012;27:148-53.
19. D'Alonzo GE, Barst RJ, Ayres SM, Bergofsky EH, Brundage $\mathrm{BH}$, Detre KM, et al. Survival in patients with primary pulmonary hypertension. Results from a national prospective registry. Ann Intern Med 1991;115:343-9.

20. Cosgun T, Tomaszek S, Opitz I, Wilhelm M, Schuurmans MM, Weder W, et al. Single-center experience with intraoperative extracorporeal membrane oxygenation use in lung transplantation. Int J Artif Organs 2018;41:89-93.

21. Armstrong HF, Schulze PC, Kato TS, Bacchetta M, Thirapatarapong W, Bartels MN. Right ventricular stroke work index as a negative predictor of mortality and initial hospital stay after lung transplantation. J Heart Lung Transplant 2013;32:603-8.

22. Humbert M, Morrell NW, Archer SL, Stenmark KR, MacLean MR, Lang IM, et al. Cellular and molecular pathobiology of pulmonary arterial hypertension. J Am Coll Cardiol 2004;43(12 Suppl S):13S-24S.

23. McLaughlin VV, McGoon MD. Pulmonary arterial hypertension. Circulation 2006;114:1417-31.

24. Hosenpud JD, Bennett LE, Keck BM, Edwards EB, Novick RJ. Effect of diagnosis on survival benefit of lung transplantation for end-stage lung disease. Lancet 1998;351:24-7.

25. Krowka MJ, Plevak DJ, Findlay JY, Rosen CB, Wiesner RH, Krom RA. Pulmonary hemodynamics and perioperative cardiopulmonary-related mortality in patients with portopulmonary hypertension undergoing liver transplantation. Liver Transpl 2000;6:443-50.

26. Zalunardo MP, Thalmann C, Seifert B, D'Cunja J, Weder $\mathrm{W}$, Boehler A, et al. Impact of preoperative right-ventricular function and platelet transfusion on outcome after lung transplantation. Eur J Cardiothorac Surg 2011;39:538-42.

27. Sitbon O, Humbert M, Nunes H, Parent F, Garcia G, Hervé $\mathrm{P}$, Rainisio $\mathrm{M}$, et al. Long-term intravenous epoprostenol infusion in primary pulmonary hypertension: prognostic factors and survival. J Am Coll Cardiol 2002;40:780-8. 